\title{
Ameliorating effect of gum arabic and lemongrass on chronic kidney disease induced experimentally in rats
}

\author{
Alshaimaa M. Said ${ }^{1 *}$ (D) Shimaa A. E. Atwa ${ }^{2}$ and Olla A. Khalifa ${ }^{3}$
}

\begin{abstract}
Background: Renal replacement therapy, either by transplantation or dialysis, is not accessible in many parts of the world because of lack of financial and clinical resources. This study was performed to investigate the nephroprotective efficiency of gum arabic (GA) and lemongrass (LG) on adenine-induced chronic kidney disease.

Materials and methods: Four animal groups (each of 10 rats) received normal saline, intraperitoneal injection of adenine $(300 \mathrm{mg} / \mathrm{kg})$ twice a week, and adenine plus oral GA $(5.4 \mathrm{~g} / \mathrm{kg})$ or oral LG $(360 \mathrm{mg} / \mathrm{kg})$ daily for 4 weeks.

Results: Compared to control group, adenine-injected rats had significantly higher levels of serum urea, creatinine, and uric acid. Moreover, biochemical analysis of kidney homogenate showed that adenine injection was associated with significantly higher levels of malondialdehyde and lower levels of reduced glutathione and antioxidant enzyme activities in comparison with normal control. Additionally, the adenine group exhibited a significant upregulation in tumor necrosis factor-a and downregulation in interleukin-10 gene expression. Histopathological and immunohistochemical examinations of renal tissue from the adenine group showed degeneration to renal glomeruli and renal tubules with increased DNA double-strand breaks. On the other hand, treatment with GA or LG ameliorated all the previous parameters to a large extent.
\end{abstract}

Conclusion: From this study, we concluded that oral administration of GA or LG could conceivably alleviate adverse effects of CKD which might be ascribed to their antioxidant and free radical-scavenging properties.

Keywords: Adenine, chronic kidney disease, Gum arabic, Lemongrass, Nephroprotective

\section{Introduction}

The prevalence and incidence of chronic kidney disease (CKD), which in its later stage termed chronic renal failure (CRF), are on worldwide increase (James et al. 2010; Nugent et al. 2011). The major factors behind this apparent increase are the environmental pollution, misuse and irrational use of drugs, and the prevalence of schistosomiasis, malaria, obesity, hypertension, and diabetes mellitus (Himmelfarb 2004). The relatively poor status of the health care system in the developing countries is at strong demand for studies into the pathophysiology and mechanisms of CKD, and exploring new effective therapeutic strategies and ameliorating agents, especially for the

\footnotetext{
* Correspondence: alshaimaa.said@fvtm.bu.edu.eg

${ }^{1}$ Biochemistry Department, Faculty of Veterinary Medicine, Benha University, Moshtohor, Toukh, Qaliobiya 13736, Egypt

Full list of author information is available at the end of the article
}

earlier stages of CKD in order to slow its progression towards CRF and reduce the cost of dialysis, drug therapy, and kidney transplantation (Ichihara et al. 2009).

Animal models are important tools in studying the different mechanisms of CKD and exploring potential therapy on these mechanisms (Desrochers et al. 2014). Adenine-induced CKD was first reported in the 1980s as an alternative method for the surgical model which is expensive and skill requiring (Al Za'abi et al. 2015). Natural products are used as an alternative approach to ameliorate the severity of CRF and reduce the frequency of dialysis.

Gum arabic is defined as an edible, dried gummy exudate obtained from the stems and branches of Acacia senegal and Acacia seyal trees that is rich in non-viscous soluble fiber and is widely used as an emulsifier and stabilizer in pharmaceutical, cosmetic, and food industry (Ali et al. 2009). It has been used in the Middle East and 
North Africa as an oral hygienic substance and anti-inflammatory for intestinal mucosa and inflamed skin (Gamal el-din et al. 2003). Addition of GA to the diet has been shown to increase fecal urea nitrogen excretion, with a concomitant decrease in serum urea nitrogen concentration (Ali et al. 2008). Therefore, GA is used for some time now in traditional medicinal practice with CRF patients (Ali et al. 2014; Becker and Hewitson 2013).

Cymbopogon citratus commonly known as lemongrass is a tall, coarse grass with a strong lemon taste and has a wide range of therapeutic, nutritional, and cosmetic uses. The plant is used as an antioxidant and anti-inflammatory, anticarcinogenic, hypoglycemic, and cardioprotective agent in folk medicine (Akande et al. 2011). Nutritionally, lemongrass is used as a flavoring spice in many cuisines and confections. Its essential oil enters in many cosmetic preparations as perfumes, soaps, detergents, and body lotions. The infusions prepared from its dry or fresh leaves are extensively used in recent years as a diuretic for treatment of urinary tract disorders as cystitis, renal stones, and urine retention and for treatment of hypertension and associated cardiovascular disorders; it is also used in the treatment of gout (Mirghani et al. 2012).

The present study aimed to evaluate the biochemical effects of GA and LG on adenine-induced CKD in a rat model through investigating their antioxidant and anti-inflammatory mechanisms.

\section{Material and method}

\section{Chemicals}

Adenine was obtained from Sigma-Aldrich (St Louis, MO, USA). Gum arabic and lemongrass were obtained from a local market.

\section{Experimental animals}

A total of 40 male Wistar albino rats weighing 150-170 $\mathrm{g}$ were supplied from the animal house of Faculty of Veterinary Medicine, Benha University, Egypt. Animals were kept in cages under proper environmental conditions of temperature, humidity, and light and had free access to food and water. The animals were acclimatized to the laboratory conditions for 2 weeks prior to the experiment. The animal handling procedures were conducted according to the ethical norms approved by the Ethical Committee of Faculty of Veterinary Medicine, Benha University.

\section{Experimental design}

Rats were randomly and equally divided into four groups (10 animals each).

- Group I (control group): received i.p injection of saline twice a week.
- Group II (adenine group): received i.p injection of adenine $(300 \mathrm{mg} / \mathrm{kg}$ b.w) twice a week (Al Za'abi et al. 2015).

- Group III (adenine + GA group): received i.p injection of adenine $(300 \mathrm{mg} / \mathrm{kg}$ b.w) twice a week and gum arabic ( $4.5 \mathrm{~g} / \mathrm{kg}$ b.w daily p.o) for 4 weeks (Ali et al. 2008).

- Group IV (adenine + LG group): received i.p injection of adenine ( $300 \mathrm{mg} / \mathrm{kg}$ b.w) twice a week and lemongrass ( $360 \mathrm{mg} / \mathrm{kg}$ b.w daily p.o) for 4 weeks (Christopher et al. 2014).

\section{Sampling}

\section{Blood sampling}

At the end of experimental period, all animals were fasted overnight and euthanized with diethyl ether. Blood samples were collected directly from the heart, and the serum was separated for biochemical analysis.

\section{Tissue sampling}

Tissue specimens from both kidneys were quickly excised, rinsed in ice-cold saline to exclude the blood cells, blotted on a filter paper, and divided into three parts. The first part was kept at $-20^{\circ} \mathrm{C}$ until used for determination of oxidative stress indices. The second part was kept at $-80^{\circ} \mathrm{C}$ for gene expression. The third part was placed in $10 \%$ formalin solution for histological and immunohistochemical investigations.

\section{Biochemical analysis \\ Evaluation of kidney function tests}

Urea, creatinine, and uric acid concentrations were spectrophotometrically determined following the procedures of Coulombe and Favreau (1963), Larsen (1972), and Young et al. (1975) respectively.

\section{Assessments of oxidative stress indices}

The kidney tissues were cut, weighed, homogenized in 4 $\mathrm{mL}$ physiological saline, and centrifuged at $5000 \mathrm{rpm}$ for $20 \mathrm{~min}$ at $4{ }^{\circ} \mathrm{C}$. The supernatant was used for determination of oxidative stress parameters. L-MDA as a marker for lipid peroxidation (Mesbah et al. 2004); reduced glutathione (non-enzymatic antioxidant, GSH) (Moron et al. 1979), catalase (CAT) (Aebi 1984), and superoxide dismutase (SOD) (Kakkar et al. 1984) activities; and total antioxidant capacity (TAC) (Benzie and Strain 1996) were determined using diagnostic kits obtained from Laboratory Biodiagnostics Co. (Cairo, Egypt).

\section{Determination of renal endothelin-1 (ET-1)}

Endothelin-1 was determined according to the method described by Rolinski et al. (1994). 


\section{Measurement of TNF-a, IL-10, and vascular endothelial growth factor (VEGF) gene expression}

Total RNA was extracted from rat kidneys using a Gene JET RNA Purification Kit (Thermo Scientific, \# K0731, USA) according to the manufacturer's protocol. Complementary DNA was synthesized using $5 \mu \mathrm{g}$ of total RNA by RevertAid $\mathrm{H}$ Minus Reverse Transcriptase (Thermo Scientific, \#EP0451, USA). The primer sequences used for amplification are summarized in Table 1. Quantitative RT-PCR for TNF- $\alpha$, IL-10, and VEGF genes was performed using a StepOnePlus RT-PCR system (Applied Biosystems, USA) with initial denaturation at $95^{\circ} \mathrm{C}$ for $10 \mathrm{~min}, 40-45$ amplification cycles at $95^{\circ} \mathrm{C}$ for $15 \mathrm{~s}$, annealing at $60^{\circ} \mathrm{C}$ for $30 \mathrm{~s}$, and extension at $72^{\circ} \mathrm{C}$ for 30 s. At the end of the last cycle, the temperature was increased from 63 to $95^{\circ} \mathrm{C}$ for melting curve analysis. The cycle threshold $(\mathrm{Ct})$ values were calculated for target genes and the $\beta$-actin as housekeeping gene, and relative gene expression was determined using the $2^{-\Delta \Delta C t}$ method (Livak and Schmittgen 2001).

\section{Histological and immunohistochemical analysis}

Parts of the removed rat kidneys were fixed in 10\% buffered formalin, embedded into paraffin blocks using conventional paraffin-embedding techniques, processed to obtain 5- $\mu \mathrm{m}$-thick sections, stained with hematoxylin and eosin (H\&E), and examined under a light microscope.

For immunostaining, paraffin-embedded renal sections were de-paraffinized (in xylene) and dehydrated sequentially in graded ethyl alcohol, followed by antigen unmasking in citrate buffer ( $\mathrm{pH} 6.0$ ); $5 \%$ normal goat or rabbit serum in phosphate buffered saline was used to block non-specific binding sites. Later, sections were incubated with primary antibodies against $\gamma$ - H2AX (Neo Markers/Lab vision, Fremont, CA, USA), followed by specific biotin-conjugated secondary antibodies. For color development, streptavidin-peroxidase kits were added to the slides and sections were counterstained with Mayer's hematoxylin.

\section{Statistical analysis}

The results were expressed as mean $\pm \mathrm{SE}$ of studied groups using the analysis of variance test (one-way

Table 1 Forward and reverse primer sequences for qRT-PCR

\begin{tabular}{ll}
\hline Genes & Primer sequences \\
\hline$\beta$-actin & Forward: ACCCACACTGTGCCCATCTA \\
& Reverse: CGTCACACTCATGATG \\
TNF-a & Forward: GCATGATCCGCGACGTGGAA \\
& Reverse: AGATCCATGCCGTTGGCAG \\
IL-10 & Forward: GTTGCCAAGCCTTGTCAGAAA \\
& Reverse: TTCTGGGCCATGGTTCTCT \\
VEGF & Forward: GATCATGCGGATCAAACCTCACC \\
& Reverse: CCTCCGGACCCAAATGCTC \\
\hline
\end{tabular}

ANOVA) followed by Duncan's multiple range test to determine the differences between the averages with statistical significance at $P \leq 0.05$. All statistical analyses were performed by Statistical Package for the Social Sciences Software (Version 18, SPSS Inc., Chicago, IL, USA).

\section{Results \\ Biochemical results}

Data in Table 2 show that intraperitoneal injection of adenine induced a significant increase in serum concentration of urea, creatinine, and uric acid versus the normal control rats. On the other hand, oral administration of GA and LG significantly but not completely restored these alterations. Interestingly, the serum concentrations of these parameters were restored near to the normal ranges after administration of the LG group when compared to the adenine + GA group.

As illustrated in Table 3, we noticed that MDA concentration was significantly increased while GSH concentration, CAT and SOD activities, and TAC were significantly decreased after adenine injection in comparison with the control group. Meanwhile, oral administration of GA and LG significantly decreased MDA concentration and increased GSH concentration, antioxidant enzyme activities, and TAC when compared to the adenine group. Moreover, LG administration exhibited a significant improvement in renal indices of oxidative stress in comparison with the adenine + GA group.

Concerning the cytokines, there is a marked upregulation in TNF- $\alpha$ and downregulation in the IL-10 gene expression in kidneys of rats injected with adenine. However, oral administration of GA and LG significantly restores these alterations. Moreover, LG administration showed better results when compared to the adenine + GA group. Intraperitoneal injection of adenine significantly increased renal ET-1 with downregulation of the VEGF gene as showed in Table 4 comparing to the control group. GA and LG were able to significantly decrease renal ET-1 and upregulate the VEGF gene.

Table 2 Effect of GA and LG oral administration on serum urea, creatinine, and uric acid (UA)

\begin{tabular}{llll}
\hline & Urea $(\mathrm{mg} / \mathrm{dL})$ & Creatinine $(\mathrm{mg} / \mathrm{dL})$ & $\mathrm{UA}(\mathrm{mg} / \mathrm{dL})$ \\
\hline Group I & $31.50 \pm 1.50^{\mathrm{d}}$ & $0.48 \pm 0.02^{\mathrm{d}}$ & $3.06 \pm 0.17^{\mathrm{d}}$ \\
Group II & $147.60 \pm 7.60^{\mathrm{a}}$ & $2.36 \pm 0.06^{\mathrm{a}}$ & $7.22 \pm 0.45^{\mathrm{a}}$ \\
Group III & $79.00 \pm 3.10^{\mathrm{b}}$ & $1.07 \pm 0.19^{\mathrm{b}}$ & $4.68 \pm 0.26^{\mathrm{b}}$ \\
Group IV & $52.35 \pm 3.50^{\mathrm{c}}$ & $0.61 \pm 0.04^{\mathrm{c}}$ & $4.41 \pm 0.17^{\mathrm{c}}$ \\
\hline
\end{tabular}

Group (I): control group. Group (II): adenine group. Group (III): adenine + GA group. Group (IV): adenine + LG group

Values represent mean \pm S.E. with the number of animals (10) in each group. Mean values with different superscript letters in the same column are significantly different at $P \leq 0.05$ 
Table 3 Effect of GA and LG oral administration on kidney oxidative stress indices

\begin{tabular}{llllll}
\hline & MDA $(\mu \mathrm{mol} / \mathrm{g})$ & GSH $(\mathrm{ng} / \mathrm{g})$ & CAT $(\mu \mathrm{mol} / \mathrm{g})$ & SOD $(\mathrm{U} / \mathrm{g})$ & TAC $(\mu \mathrm{mol} / \mathrm{g})$ \\
\hline Group I & $24.98 \pm 1.28^{\mathrm{d}}$ & $7.48 \pm 0.32^{\mathrm{a}}$ & $75.72 \pm 2.10^{\mathrm{a}}$ & $54.93 \pm 1.85^{\mathrm{a}}$ & $48.39 \pm 1.21^{\mathrm{a}}$ \\
Group II & $59.02 \pm 1.94^{\mathrm{a}}$ & $1.90 \pm 0.12^{\mathrm{d}}$ & $25.33 \pm 2.21^{\mathrm{d}}$ & $13.83 \pm 2.14^{\mathrm{d}}$ & $12.09 \pm 1.05^{\mathrm{d}}$ \\
Group III & $41.46 \pm 1.40^{\mathrm{b}}$ & $3.07 \pm 0.22^{\mathrm{c}}$ & $44.46 \pm 1.42^{\mathrm{c}}$ & $23.59 \pm 1.69^{\mathrm{c}}$ & $25.85 \pm 2.23^{\mathrm{c}}$ \\
Group IV & $31.24 \pm 1.13^{\mathrm{c}}$ & $5.24 \pm 0.42^{\mathrm{b}}$ & $50.08 \pm 1.19^{\mathrm{b}}$ & $39.67 \pm 1.24^{\mathrm{b}}$ & $37.95 \pm 1.34^{\mathrm{b}}$ \\
\hline
\end{tabular}

Group (I): control group. Group (II): adenine group. Group (III): adenine + GA group. Group (IV): adenine + LG group

Values represent mean \pm S.E. with the number of animals (10) in each group. Mean values with different superscript letters in the same column are significantly different at $P \leq 0.05$

\section{Immunohistochemical results}

Intraperitoneal adenine injection significantly increased the protein expression of $\gamma-\mathrm{H} 2 \mathrm{AX}$ within the renal tubules (Fig. 1b) in comparison with the control group which revealed mild or absent immunoreactivity (Fig. 1a). Adenine-injected rats that received either GA (Fig. 1c) or LG (Fig. 1d) showed significant reductions in the expression of $\gamma-\mathrm{H} 2 \mathrm{AX}$ in comparison to the adenine group.

\section{Histopathological changes in the renal cortex}

Control rats showed normal renal histology (Fig. 2a), whereas those injected with adenine exhibited marked pathological alterations as degeneration of the renal glomeruli and renal tubules with loss of architecture and disorganization (Fig. 2b). On the other hand, oral administration of GA (Fig. 2c) and LG (Fig. 2d) preserves to a large extent the normal architecture of the renal cortex except for slight degeneration and cystic dilatation of some renal tubules.

\section{Discussion}

The increasing incidence of CKD and the limitation of renal replacement therapy, either by transplantation or dialysis, especially in developing countries due to a lack of financial and clinical resources requires exploring new strategies to delay the onset of dialysis or to attenuate uremia (Jain et al. 2012). In the current study, we assessed the effects of GA and LG oral administration on several biochemical, antioxidant, and inflammatory parameters in an adenine-induced CKD model in rats. The results

Table 4 Effect of GA and LG on expression of TNF-a, IL-10, and VEGF genes and ET-1

\begin{tabular}{lllll}
\hline & TNF-a & IL-10 & VEGF & ET-1 $(\mathrm{pg} / \mathrm{mg})$ \\
\hline Group I & $1.00 \pm 0.06^{\mathrm{d}}$ & $1.00 \pm 0.05^{\mathrm{a}}$ & $1.00 \pm 0.04^{\mathrm{a}}$ & $4.35 \pm 0.32^{\mathrm{d}}$ \\
Group II & $5.21 \pm 0.30^{\mathrm{a}}$ & $0.21 \pm 0.02^{\mathrm{d}}$ & $0.20 \pm 0.02^{\mathrm{d}}$ & $37.59 \pm 1.40^{\mathrm{a}}$ \\
Group III & $2.81 \pm 0.20^{\mathrm{b}}$ & $0.41 \pm 0.03^{\mathrm{c}}$ & $0.43 \pm 0.04^{\mathrm{c}}$ & $19.45 \pm 0.95^{\mathrm{b}}$ \\
Group IV & $1.78 \pm 0.14^{\mathrm{c}}$ & $0.48 \pm 0.03^{\mathrm{b}}$ & $0.71 \pm 0.05^{\mathrm{b}}$ & $8.23 \pm 0.71^{\mathrm{c}}$ \\
\hline
\end{tabular}

Group (I): control group. Group (II): adenine group. Group (III): adenine + GA group. Group (IV): adenine + LG group

Values represent mean \pm S.E. with the number of animals (10) in each group.

Mean values with different superscript letters in the same column are

significantly different at $P \leq 0.05$ indicated that concomitant treatment with GA and LG ameliorated the adverse effects induced by adenine.

Induction of CRF by adenine in rats is a standard method for simulating a metabolic abnormality which occurs in humans suffering from renal failure (Ali et al. 2013b). It was reported that adenine-rich diets suppress the excretion of nitrogenous compounds due to renal tubular occlusion. Adenine becomes a target, when present in excess, for xanthine dehydrogenase and oxidized to 2,8-dihydroxyadenine crystals. Adenine and its metabolite (DHA) precipitate in the renal tubules leading to their occlusion (Adachi et al. 1998). Our results came in accordance with this theory as shown in (Table 1). Moreover, there is evidence on inflammation and oxidative stress of renal tissues observed in adenine-induced CKD (Al Za'abi et al. 2015) as seen in the present study (Tables 3 and 4). This is consistent with previous observations of Carrero and Stenvinkel (2010) as well as Kinugasa (2011) who found that CKD patients have high plasma concentration of inflammatory and oxidative stress markers. Also, lipid peroxidation as an oxidative stress marker and $C$ reactive protein (CRP) as an inflammatory marker are reported by other studies to be increased (Annuk et al. 2001; Shlipak et al. 2003).

Remarkably, in the current study, a significant reduction in serum concentration of urea, creatinine, and uric acid was observed in adenine-induced CKD rats receiving a daily oral dose of gum arabic. GA has been used recently in several developing countries to treat CKD since it has been reported to decrease serum urea nitrogen concentration and increase fecal nitrogen excretion by utilizing the bowl as a substitute kidney (Ali et al. 2009). It has been assumed that GA increases the available energy to the intestinal bacteria which ferment dietary fibers and obtain their nitrogen requirement from the nitrogen waste product of the host (Ali et al. 2004; Ali et al. 2009). They also degrade urea to ammonia, which is excreted with some of the body nitrogen waste in feces (Younes et al. 1995; Bliss et al. 1996). Moreover, a considerable cecum enlargement, by increasing its contents, wall thickness, and blood flow, was observed after consuming fermentable fibers. These changes decrease plasma urea concentration by $30 \%$ through enhancement of urea nitrogen uptake into the cecum (Younes et al. 2006). 

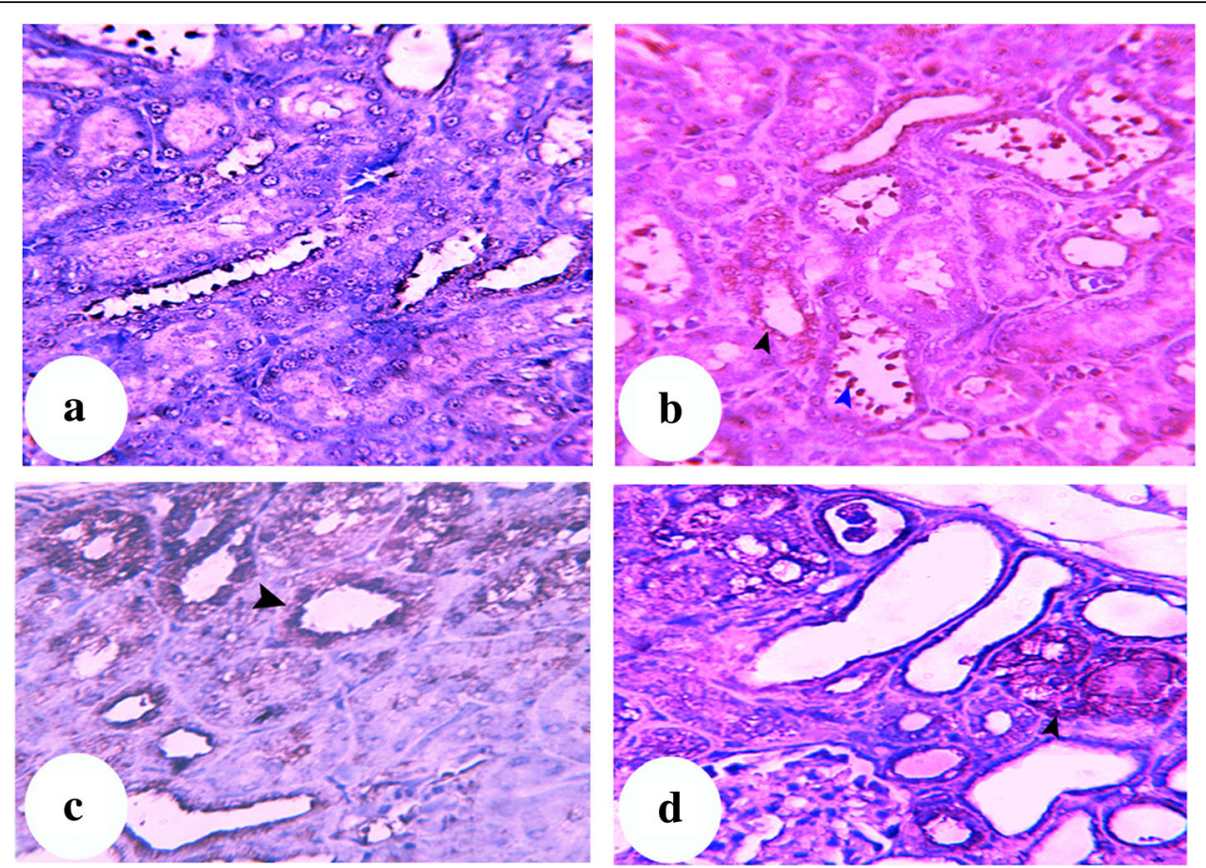

Fig. 1 Y-H2AX immunohistochemical expression in the renal cortex. a Control group showed minimal $\gamma-H 2 A X$ expression. b Adenine group showed many $\gamma$-H2AX-positive cells (arrowhead). c Adenine + GA group showed moderate reduction in $\gamma$-H2AX-positive cells (arrowhead). $\mathbf{d}$ Adenine + LG group showed minimal $Y-H 2 A X$ expression (arrowhead)

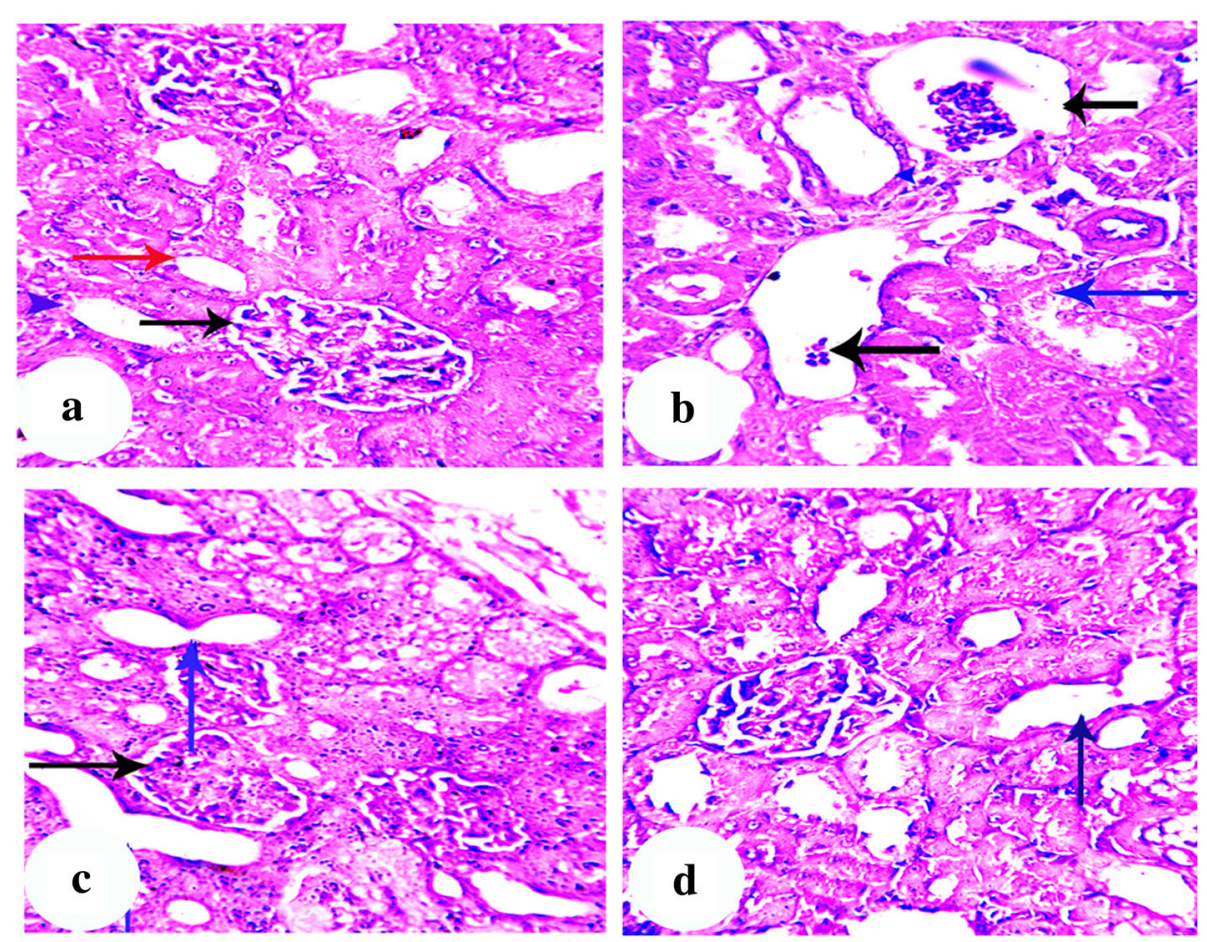

Fig. 2 Renal cortex; Rat. a Control group showing normal histological architecture. b Adenine group showing degeneration to renal glomeruli (black arrow), degenerative changes (blue arrow) and loss of architecture in PCTs and DCTs. c Adenine + GA group showing moderate histopathologic changes (blue arrow). d Adenine + LG group showing mild morphologic changes (arrow). HE stain, $\times 400$ 
Recently, GA has been found to act as an antioxidant and anti-inflammatory agent in addition to its beneficial effects on kidney function (Ali et al. 2013a; Ali et al. 2013b). Our data explored the antioxidant effect of GA as confirmed by the significant reduction in MDA and increase in GSH, TAC, and antioxidant enzyme activities in kidney tissue of the adenine + GA group. These results are consistent with the previous record of $\mathrm{Al} \mathrm{Za'abi}$ et al. (2015) who suggested the main mechanism for the beneficial action of GA in adenine-induced CKD via its antioxidant properties.

Moreover, anti-inflammatory properties of GA was observed in maintaining, to some extent, the balance between renal expression of pro-inflammatory (TNF- $\alpha$ ) and anti-inflammatory (IL-10) cytokines in rats received daily oral dose of GA concomitant with i.p injection of adenine when compared to the adenine group as illustrated in Table 4. Adenine-induced CKD was proven to induce inflammatory reaction in kidney tissue in the form of increased serum CRP and increased TNF- $\alpha$ in CRF subjects while using GA in both studies mitigated this action (Mahmoud et al. 2012; Ali et al. 2013a). A possible contributing mechanism to the effect of GA on nitric oxide (NO) metabolites, which consequently affect the level of TNF- $\alpha$, in rats with renal failure might result from the antioxidant and anti-inflammatory properties of GA (Al Suleimani et al. 2015). On the other hand, GA has been reported to suppress gut inflammation in IL-10-deficient mice (Bassaganya-Riera et al. 2011).

It is important to highlight that oxidative stress played an important role in the pathogenesis of CKD and its complications including impairment of protein and DNA synthesis and cellular repair mechanisms (Perazella and Moeckel 2010). As far as we know, there are few reports on DNA damage in kidney disease. Ali et al. (2013a) and Schupp et al. (2011) attributed the DNA damage, single- and double-strand breaks, in there models to the increased oxidative stress. The first step in recruiting and localizing DNA repair proteins is $\gamma$-H2AX, a newly phosphorylated histone observed in nucleosomes after DNA damage (Kuo and Yang 2008). Decreasing superoxide anions and oxidative stress through oral administration of GA in the present study lowered the incidence of DNA double-strand breaks to a certain extent.

Furthermore, a previous study ascribed the positive effect of GA in lowering the hypertension, a complication of CKD, observed in adenine-treated rats to its antioxidant power since reactive oxygen species (ROS) increased in animals with hypertension (Ali et al. 2011). The significant increase in endothelin-1 (ET-1), a vasoconstrictor secreted by endothelial cells (Marasciulo et al. 2006), in the adenine group may be attributed to the high level of free radicals and cytokines (Ali et al. 2013a). Vascular endothelial growth factor (VEGF), an angiogenic inducer, is downregulated by ET-1 as previously reported (Ferrara 2004). On the other hand, Al Suleimani et al. (2015) examined the effect of adenine-induced CKD on angiogenesis and found no significant difference in plasma level of ET-1 and VEGF in spite of the previous study of Ali et al. (2011) which revealed several vascular changes including blood pressure and heart rate in rats with adenine-induced CRF.

Oral administration of LG to adenine-injected rats exhibited a significant decrease in serum urea, creatinine, and uric acid indicating an effective role of LG on kidney function which may be attributed to its diuretic effect. The phytochemical constituents of LG interfere with electrolyte and water reabsorption through renal tubules which consequently enhance the excretion of nitrogenous compounds (Christopher et al. 2014) as recorded in the present study.

Our data explored the antioxidant effect of LG as confirmed by decreased MDA level and increased antioxidant enzyme activities in kidney tissue of the adenine + LG group. This is supported by the previous finding of Arhoghro et al. (2014) who noted that aqueous leaf extract of LG ameliorated cisplatin-induced oxidative damage on the liver via its antioxidant and free radical-scavenging properties. Moreover, the renal protective effect of LG against gentamicin-induced toxicity could be attributed to its strong flavonoid content and antioxidant properties (Ullah et al. 2013) which consequently affect ET-1 and VEGF as shown in (Table 4).

We consistently observed that LG administration inhibits TNF- $\alpha$ expression that coincides with the record by Francisco et al. (2013) who attributed the anti-inflammatory effect of LG to its phenolic content and inhibition of nuclear factor- $\kappa \beta$ pathway and cytokine expression. In addition, scavenging the ROS, which act as potential contributors to inflammation in CKD (Cachofeiro et al. 2008), plays an important role in its anti-inflammatory effect.

These biochemical findings were further confirmed by evidences of microscopic examinations. In this study, degenerative changes to renal glomeruli induced by i.p injection of adenine markedly attenuated by oral administration of GA and LG which might be attributed to their free radical-scavenging activities.

\section{Conclusion}

Oral administration of GA and LG daily for 4 weeks successfully ameliorated the adenine renal damaging as evidenced by biochemical, immunohistochemical, and histopathological examination. The possible mechanisms of this action might be ascribed to their antioxidant and anti-inflammatory properties. 


\section{Acknowledgements}

The authors are grateful to Biochemistry Dept. animal house for looking after the rats and for technical help in the early stages of this work.

\section{Funding}

This research did not receive any specific grant from funding agencies in the public, commercial, or not-for-profit sectors.

\section{Availability of data and materials}

All data generated or analyzed during this study are included in this published article.

\section{Authors' contributions}

AMS conceived and designed the experiments. AMS and SAEA performed the experiments. AMS analyzed the data. OAK performed the PCR analysis. AMS, SAEA, and OAK wrote the paper. All authors read and approved the final manuscript.

\section{Ethics approval and consent to participate}

The animal handling procedures were conducted according to the ethical norms approved by the Ethical Committee of Faculty of Veterinary Medicine, Benha University.

\section{Consent for publication}

Not applicable

\section{Competing interests}

The authors declare that they have no competing interests.

\section{Publisher's Note}

Springer Nature remains neutral with regard to jurisdictional claims in published maps and institutional affiliations.

\section{Author details}

'Biochemistry Department, Faculty of Veterinary Medicine, Benha University, Moshtohor, Toukh, Qaliobiya 13736, Egypt. ${ }^{2}$ Biochemistry Department, Educational Hospital, Faculty of Veterinary Medicine, Benha University, Moshtohor, Toukh, Qaliobiya 13736, Egypt. ${ }^{3}$ Animal Wealth Development Department, Faculty of Veterinary Medicine, Benha University, Moshtohor, Toukh, Qaliobiya 13736, Egypt.

\section{Received: 8 January 2019 Accepted: 12 March 2019}

\section{Published online: 25 March 2019}

\section{References}

Adachi Y, Sasagawa I, Tateno T, Tomaru M, Kubota Y, Nakada T (1998) Influence of adenine-induced chronic renal failure on testicular function in the rat. Andrologia 30(2):115-118

Aebi H (1984) Catalase in vitro. Methods Enzymol 105:121-126

Akande IS, Samuel TA, Agbazue U, Olowolagba BL (2011) Comparative proximate analysis of ethanolic and water extracts of Cymbopogon citratus (lemon grass) and four tea brands. Plant Sci Res 3:29-35

Al Suleimani YM, Al Za'abi M, Ramkumar A, Al Mahruqi AS, Tageldin MH, Nemmar A, Ali BH (2015) Influence of treatment with gum acacia on renal vascular responses in a rat model of chronic kidney disease. Eur Rev Med Pharmacol Sci 19(3):498-506

Al Za'abi M, Al Busaidi M, Yasin J, Schupp N, Nemmar A, Ali BH (2015) Development of a new model for the induction of chronic kidney disease via intraperitoneal adenine administration, and the effect of treatment with gum acacia thereon. Am J Transl Res 7(1):28-38

Ali AA, Ali KE, Fadlalla AE, Khalid KE (2008) The effects of gum arabic oral treatment on the metabolic profile of chronic renal failure patients under regular haemodialysis in Central Sudan. Nat Prod Res 22(1):12-21

Ali BH, Al-Husseni I, Beegam S, Al-Shukaili A, Nemmar A, Schierling S, Queisser N, Schupp N (2013a) Effect of gum arabic on oxidative stress and inflammation in adenine-induced chronic renal failure in rats. PLoS One 8(2):e55242

Ali BH, Alqarawi AA, Ahmed IH (2004) Does treatment with gum arabic affect experimental chronic renal failure in rats? Fundam Clin Pharmacol 18(3):327-329

Ali BH, Al-Salam S, Al Za'abi M, Waly Ml, Ramkumar A, Beegam S, Al-Lawati I, Adham SA, Nemmar A (2013b) New model for adenine-induced chronic renal failure in mice, and the effect of gum acacia treatment thereon: comparison with rats. J Pharmacol Toxicol Methods 68(3):384-393

Ali BH, Alza'abi M, Ramkumar A, Al-Lawati I, Waly MI, Beegam S, Nemmar A Brand S, Schupp N (2014) The effect of activated charcoal on adenineinduced chronic renal failure in rats. Food Chem Toxicol 65:321-328

Ali BH, Ziada A, Al Husseni I, Beegam S, Al-Ruqaishi B, Nemmar A (2011) Effect of Acacia gum on blood pressure in rats with adenine-induced chronic renal failure. Phytomedicine 18(13):1176-1180

Ali BH, Ziada A, Blunden G (2009) Biological effects of gum arabic: a review of some recent research. Food Chem Toxicol 47(1):1-8

Annuk M, Zilmer M, Lind L, Linde T, Fellstrom B (2001) Oxidative stress and endothelial function in chronic renal failure. J Am Soc Nephrol 12(12): 2747-2752

Arhoghro EM, Ikeh C, Prohp TP (2014) Cymbopogon citratus aqueous extract alleviates cisplatin-induced hepatic oxidative stress and toxicity in albino rats. Int J Curr Microbiol Appl Sci 3:586-604

Bassaganya-Riera J, DiGuardo M, Viladomiu M, de Horna A, Sanchez S, Einerhand AW, Sanders L, Hontecillas R (2011) Soluble fibers and resistant starch ameliorate disease activity in interleukin-10-deficient mice with inflammatory bowel disease. J Nutr 141(7):1318-1325

Becker GJ, Hewitson TD (2013) Animal models of chronic kidney disease: useful but not perfect. Nephrol Dial Transplant 28(10):2432-2438

Benzie IF, Strain JJ (1996) The ferric reducing ability of plasma (FRAP) as a measure of "antioxidant power": the FRAP assay. Anal Biochem 239(1):70-76

Bliss DZ, Stein TP, Schleifer CR, Settle RG (1996) Supplementation with gum arabic fiber increases fecal nitrogen excretion and lowers serum urea nitrogen concentration in chronic renal failure patients consuming a lowprotein diet. Am J Clin Nutr 63(3):392-398

Cachofeiro V, Goicochea M, de Vinuesa SG, Oubina P, Lahera V, Luno J (2008) Oxidative stress and inflammation, a link between chronic kidney disease and cardiovascular disease. Kidney Int. Supplement 74(111):4-9

Carrero JJ, Stenvinkel P (2010) Inflammation in end-stage renal disease-what have we learned in 10 years? Semin Dial 23(5):498-509

Christopher E, Nyebuk D, Ernest A (2014) Phytoconstituents and diuretic activity of Cymbopogon citratus leaf infusions in humans. J Coastal Life Med 2(9): 704-713

Coulombe JJ, Favreau L (1963) A new simple semimicro method for colorimetric determination of urea. Clin Chem 9:102-108

Desrochers TM, Palma E, Kaplan DL (2014) Tissue-engineered kidney disease models. Adv Drug Deliv Rev 69-70:67-80

Ferrara N (2004) Vascular endothelial growth factor: basic science and clinical progress. Endocr Rev 25(4):581-611

Francisco V, Costa G, Figueirinha A, Marques C, Pereira P, Miguel Neves B, Celeste Lopes M, Garcia-Rodriguez C, Teresa Cruz M, Teresa Batista M (2013) Antiinflammatory activity of Cymbopogon citratus leaves infusion via proteasome and nuclear factor-kappaB pathway inhibition: contribution of chlorogenic acid. J Ethnopharmacol 148(1):126-134

Gamal el-din AM, Mostafa AM, Al-Shabanah OA, Al-Bekairi AM, Nagi MN (2003) Protective effect of arabic gum against acetaminophen-induced hepatotoxicity in mice. Pharmacol Res 48(6):631-635

Himmelfarb J (2004) Linking oxidative stress and inflammation in kidney disease: which is the chicken and which is the egg? Semin Dial 17(6):449-454

Ichihara A, Sakoda M, Kurauchi-Mito A, Narita T, Kinouchi K, Itoh H (2009) Drug discovery for overcoming chronic kidney disease (CKD): new therapy for CKD by a (pro)renin-receptor-blocking decoy peptide. J Pharmacol Sci 109(1):20-23

Jain AK, Blake P, Cordy P, Garg AX (2012) Global trends in rates of peritoneal dialysis. J Am Soc Nephrol 23(3):533-544

James M, Hemmelgarn B, Tonelli M (2010) Early recognition and prevention of chronic kidney disease. Lancet 375:1296-1309

Kakkar P, Das B, Viswanathan PN (1984) A modified spectrophotometric assay of superoxide dismutase. Indian J Biochem Biophys 21(2):130-132

Kinugasa E (2011) Markers and possible uremic toxins: Japanese experiences. Contrib Nephrol 168:134-138

Kuo LJ, Yang LX (2008) Gamma-H2AX - a novel biomarker for DNA double-strand breaks. In Vivo 22(3):305-309

Larsen K (1972) Creatinine assay in the presence of protein with LKB 8600 Reaction Rate Analyser. Clin Chim Acta 38(2):475-476

Livak KJ, Schmittgen TD (2001) Analysis of relative gene expression data using real-time quantitative PCR and the 2(-Delta Delta $C(T)$ ) method. Methods 25(4):402-408 
Mahmoud MF, Diaai AA, Ahmed F (2012) Evaluation of the efficacy of ginger, Arabic gum, and Boswellia in acute and chronic renal failure. Ren Fail 34(1): 73-82

Marasciulo FL, Montagnani M, Potenza MA (2006) Endothelin-1: the yin and yang on vascular function. Curr Med Chem 13(14):1655-1665

Mesbah L, Boulkour S, Narimane S, Fillastre JP (2004) Protective effect of flavonoides against the toxity of vinblastine, cyclophosphamide and paracetamol by inhibition of lipid-peroxydation and increase of liver glutathion. Haematology 7:59-67

Mirghani MES, Liyana Y, Parveen J (2012) Bioactivity analysis of lemongrass (Cymbopogan citratus) essential oil. Int Food Res J 19:569-575

Moron MS, Depierre JW, Mannervik B (1979) Levels of glutathione, glutathione reductase and glutathione $\mathrm{S}$-transferase activities in rat lung and liver. Biochim Biophys Acta 582(1):67-78

Nugent R, Fathima SF, Feigl A, Chyung D (2011) The burden of chronic kidney disease on developing nations: a 21st century challenge in global health. Nephron Clin Pract 118:269-277

Perazella MA, Moeckel GW (2010) Nephrotoxicity from chemotherapeutic agents: clinical manifestations, pathobiology, and prevention/therapy. Semin Nephrol 30(6):570-581

Rolinski B, Sadri I, Bogner J, Goebel FD (1994) Determination of endothelin-1 immunoreactivity in plasma, cerebrospinal fluid and urine. Res Exp Med 194(1):9-24

Schupp N, Kolkhof P, Queisser N, Gartner S, Schmid U, Kretschmer A, Hartmann E, Oli RG, Schafer S, Stopper H (2011) Mineralocorticoid receptor-mediated DNA damage in kidneys of DOCA-salt hypertensive rats. FASEB J 25(3):968-978

Shlipak MG, Fried LF, Crump C, Bleyer AJ, Manolio TA, Tracy RP, Furberg CD, Psaty BM (2003) Elevations of inflammatory and procoagulant biomarkers in elderly persons with renal insufficiency. Circulation 107(1):87-92

Ullah N, Khan MA, Khan T, Ahmad W (2013) Cymbopogon citratus protects against the renal injury induced by toxic doses of aminoglycosides in rabbits. Indian J Pharm Sci 75(2):241-246

Younes H, Egret N, Hadj-Abdelkader M, Remesy C, Demigne C, Gueret C, Deteix P, Alphonse JC (2006) Fermentable carbohydrate supplementation alters nitrogen excretion in chronic renal failure. J Ren Nutr 16(1):67-74

Younes H, Garleb K, Behr S, Remesy C, Demigne C (1995) Fermentable fibers or oligosaccharides reduce urinary nitrogen excretion by increasing urea disposal in the rat cecum. J Nutr 125(4):1010-1016

Young DS, Pestaner LC, Gibberman V (1975) Effects of drugs on clinical laboratory tests. Clin Chem 21(5):1d-432d

\section{Submit your manuscript to a SpringerOpen ${ }^{\circ}$ journal and benefit from:}

- Convenient online submission

- Rigorous peer review

- Open access: articles freely available online

- High visibility within the field

- Retaining the copyright to your article

Submit your next manuscript at $\boldsymbol{\nabla}$ springeropen.com 